Pp. $\mathrm{x}+615$ ), adds another valuable treatise to his already long list of studies on the legal history of France. Though less extensive in scope than his Histoire des institutions politiques et administratives de la France it comes up to the same high standard in point of scholarship and method. While the present work deals principally with the king and his ministers, the latter term is employed in its largest sense to include all the important delegates of the royal power and their history and functions are treated in relation to the great services with which they were associated, so that we have much more than a history simply of the royal office. Starting with a summary of the formation of the kingdom he traces the growth of the royal power, analyzes the theory of divine right which occupied such an important place in the theory of the royal power, and discusses the relation of the king of France to the papacy and to the emperor, the liberties of the Gallican Church, the origin of the secretaries of state, the chancellor, the public finances, the army, the marine, the great publio services (mines, waters, forests, roads, bridges, and posts), the intendants, the parliaments and the provincial assemblies. Every page is illuminated with copious explanatory footnotes and bibliographical citations showing evidence of the widest research and painstaking industry. While the work is mainly historical in character it is indispensable to the study of the existing legal institutions of France since it is only by studying them in their historical relations that one can properly understand them as they are today. Monsieur Viollet holds out the promise that if time is spared him he expects to treat the clergy, the states-general, the judiciary and the finances of the monarchy in a later work. He has thrown so much light on the subjects already treated by him that legal and historical scholars the world over will rejoice to see him complete the work so admirably begun.

\title{
NEW HAMPSHIRE CONSTITUTIONAL CONVENTION
}

FRANK A. UPDYKE

\section{Dartmouth College}

New Hampshire has the unique, but not over laudable distinction, of being the only State in the Union which amends its constitution only through the medium of a constitutional convention. The constitution provides that the question of revision shall be submitted to the people once in seven years. If a majority of those voting upon the question 
vote affirmatively the legislature is required to make provision for calling a constitutional convention. This convention is composed of the same number of members, and elected in the same manner, as the representatives to the lower house of the legislature. Amendments proposed by the convention must, to become law, receive a two-thirds vote of those voting thereon.

The people of New Hampshire have been exceedingly conservative in making changes in their fundamental law. The original constitution of 1784 , with modifications made in 1793 , has continued to the present time with comparatively few changes. Since 1793 there have been only five constitutional conventions, the people having upon sixteen different occasions voted negatively upon the question of calling a convention. These five conventions have submitted altogether sixty-one amendments. Of these twenty-six have been adopted.

The mode of amending the constitution of New Hampshire is such as to discourage constitutional changes, even though such changes may be desirable. In the first place, it is generally held that a constitutional convention can not be convened oftener than seven years. Usually the periods between conventions have been much longer. In the second place, the procedure attending the convening of a convention covers a period of from two to three years. To illustrate, the New Hampshire legislature in March, 1909, voted to submit the question of calling a convention to the voters of the towns. This vote was taken at the November election, 1910. A majority having voted in the affirmative, the legislature, in April, 1911, made provision for convening a constitutional convention in June 1912. The towns in the March elections in 1912 elected delegates to this convention. The proposed amendments passed by this convention were submitted to the electorate at the November elections in 1912, nearly three years from the time when the first step was taken in the direction of calling a constitutional convention.

The last convention met, pursuant to the act of the state legislature, the fifth of June, 1912, and continued in session until the twenty-second of June. The convention was composed of 413 delegates. These had been 'elected, for the most part, upon party tickets, though a few were elected upon independent nomination papers. Though the convention was, supposedly, non-partisan, the usual bi-partisan arrangement was at once made in caucus, the Republicans naming the president and the Democrats the clerk of the convention. The regular Republican employees of the house of representatives were retained. The lines of division in the convention were, on the whole, not between Republicans 
and Democrats, but between conservatives and progressives irrespective of party. The convention was, save for about twenty minutes of the day before the closing of the session when the bill for taxing income of public service corporations was passed, well under the control of New Hampshire's old guard politicians. These men not only named the officers of the convention and through farcical proceedings took possession of the best seats in the house, but they controlled the committees and the proceedings of the convention. Word was passed along at the outset of the convention that all progressive measures should be stifled. To this end care was taken in the appointment of committees not to include those interested in measures to thich the "stand patters". were opposed.

Notwithstanding the fact that the reactionary character of the convention gave little hope of any thoughtful consideration of proposed changes to the constitution, fifty-nine resolutions were submitted. Of these fifty-nine measures six had to do with the taxation of forest lands and intangibles, enabling the legislature to tax such properties at different rates from other taxable property. The taxation question was considered the most important of any coming before the convention and it was with the expectation that the constitutional convention would offer some relief to present methods of taxation of forest lands and intangibles that the convention was called. Nine resolutions were presented relating to the reduction of the house of representatives which at present has the largest membership of any State in the Union. Four proposals were made in the direction of increasing the size of the senate which now numbers only twenty-four. Three resolutions were introduced providing for a legislative mode of amendment. In connection with the short ballot movement in New Hampshire five resolutions were introduced relating to the appointment of county officers.

Other important proposals were, the initiative and referendum, woman suffrage, plurality elections, taxation of incomes, councillor and senatorial districts to be based upon population, income tax upon public service corporations, conviction of bribery and violation of election laws made a disqualification for voting and holding office, provision for home rule for cities, governor given power to veto items of appropriation bill, words evangelical and protestant to be stricken from the constitution, extending the jurisdiction of justices of the peace, and provision with respect to an inheritance tax.

Of the fifty-nine resolutions introduced covering thirty-four subjects only twelve were passed by the convention.

These proposed amendments were as follows: 
1. To increase the senate to thirty-six and to divide the State into senatorial districts on the basis of population.

2. To decrease the size of the house of representatives by making twenty-four hundred instead of eighteen hundred the ratio for representation in towns for the second and additional representatives.

3. To empower the legislature to specially assess, rate and tax growing wood and timber and money at interest.

4. To provide for a graduated inheritance tax.

5. To empower the legislature to impose a tax upon the income of public service corporations.

6. To strike out the words evangelical and protestant in the bill of rights of the constitution.

7. To disqualify for voting or holding office any person convicted of treason, bribery, or wilful violation of the election laws.

8. To provide for plurality in place of majority elections in the case of governor, councillors and senators.

9. To amend the bill of rights by striking out the provision that pensions shall not be granted for more than one year at a time.

10. To empower the legislature to increase the jurisdiction of police courts so as to include all crimes not punishable by confinement in the state prison.

11. To provide that councillor districts be based upon population instead of property.

12. To allow the governor to veto separate items of an appropriation bill.

The subjects which received most discussion in the convention were those of taxation, increasing the size of the house of representatives, woman suffrage and the initiative and referendum. The last two measures were defeated by the following vote: woman suffrage, 208 to 149 ; initiative and referendum, 177 to 157 . It was quite apparent that the same two factors contributed very largely to the defeat of both of these measures. These were the corporations and the liquor interests.

Of the twelve proposed amendments submitted to the voters at the November election only four were adopted and these were all of minor importance. Those which secured the necessary two-thirds vote were: the amendment regarding disqualification for voting and holding office for conviction of bribery and violation of election laws; plurality elections; extension of jurisdiction of police courts; councillor districts to be based on population. Much disappointment was felt over the failure of the others, particularly the one relating to taxation of forest lands 
and intangible property. It has been proposed that the president of the convention reconvene the convention in order to formulate another proposal with reference to taxation of forests, and that such proposal be submitted to the voters at the March elections. The convention can be reconvened in this way, for when it adjourned it did so subject to the call of the president. This will probably be done for Governor Felker in his inaugural address has recommended that the legislature make sufficient appropriation for reconvening the constitutional convention to the end that that body may consider the advisability of submitting any proposed changes to the constitution to the voters to be voted on at the March elections. This would enable the present legislature to pass legislation in accordance with any changes that might be approved by the people. Governor Felker in his recommendation pertinently suggests the desirability of an amendment allowing the legislature to propose amendments. Certainly the results of the constitutional convention of 1912 emphasize the need of such change. Many believe that this is the most important amendment that could be adopted.

\section{RECENT DECISIONS OF STATE COURTS ON POINTS OF PUBLIC LAW}

Executive power. State vs. Rhame. (South Carolina, September 21, 1912. 75 S. E. 881.) Power of removal from office not incident to office of governor, nor incident to power of appointment, if term is fixed by statute. Implied power also negatived by express grant of more limited power. Two judges dissent.

Method of passing statutes. Baltimore Fidelity, etc., Company vs. Canton Lumber Company. (Maryland, May 10, 1912. 88 Atl. 188.) The constitution is not violated by the willing return of a bill by the governor to one branch of the legislative at its request, supported by the concurrent action of the other branch in making such request. Distinguished from People vs. Devlin, 33 N. Y. 269.

Method of passing statutes-Amending acts. Lyons vs. Police Pension Board. (Illinois, June, 21 1912. 99 N. E. 337.) Under the constitutional provision requiring the section amended to be inserted at length in the new act, a new provision which in substance amends a section of a prior act, cannot be framed as an additional section. 